\title{
Reproducibility of Oral Glucose Tolerance Tests with Three Different Loads*
}

\author{
M. Toeller and R. Knußmann, \\ Diabetes Research Institute at the University of Düsseldorf \\ Received: September 21, 1972, accepted: November 15, 1972
}

\begin{abstract}
Summary. Oral glucose tolerance tests $(5 \times 50 \mathrm{~g}, 5 \times$ $75 \mathrm{~g}$ and $5 \times 100 \mathrm{~g}$ glucose load) were carried out in 20 healthy male volunteers on 15 separate occasions at intervals of 3 or 4 days. The mean age of the group of younger men was 39.4 years and of the group of older men, 68.2 years. One and two hours after the administration of $100 \mathrm{~g}$ glucose the whole group showed a significantly smaller individual variation of blood sugar response than after both 50 and $75 \mathrm{~g}$. When subdividing the groups of
\end{abstract}

young and old men the same trend was noted. Oral glucose tolerance tests with a $100 \mathrm{~g}$ glucose load showed a greater reproducibility than those with a 50 and a $75 \mathrm{~g}$ glucose load.

Key words: Oral glucose tolerance tests, different glucose loads, variation of blood sugar response, reproducibility.

\section{Introduction}

For many years it has been known that glueose tolerance tests are not stable on repetition. Under similar conditions the same individuals may show dissimilar blood glucose levels at coincident times after glucose ingestion.

A review of the literature shows that there have been few investigations with more than duplicate determinations of blood glucose within a short time and most of the tests were only performed with a single oral glucose load (Bock, Schneider, Gilbert, 1926; Hale-White and Payne, 1926; Lennox, 1927; Glassberg, 1930; John, 1934; Freeman et al., 1942; Hofstatter et al., 1945; Mosenthal and Barry, 1950; Unger, 1957 ; McDonald et al., 1965; Castro et al., 1970).

This report presents a study of the reproducibility of oral glucose tolerance tests with three different loads.

\section{Materials}

20 healthy male volunteers without known diabetes or any other condition that might affect their blood sugar levels wore investigated. 15 oral glucose tolerance tests were carried out on each subject at intervals of 3 or 4 days. The glucose load consisted of 50,75 and $100 \mathrm{~g}$, each dose being given five times to each subject (Table 1).

Three subjects were only tested on five occasions with a $50 \mathrm{~g}$ glucose load. One of them became ill, another one was excluded at his own request and a third was found to be diabetic.

The 11 younger men were administration officials of Düsseldorf with a mean age of 39.4 years. The other 9 men were living in a home for the aged, their mean age being 68.2 years. Body weight deviated from the ideal by a mean of $+15.4 \%$ for the young group and $+2.2 \%$ for the old group (Metropolitan Life Insurance Company tables, 1959; Knußmann et al., 1972).

* Presented at the Annual Meeting of the European Diabetes Epidemiology Study Group. Bern, Switzerland, May 1972.
Methods

Glucose tolerance tests were performed under comparable conditions. No drugs were allowed for the entire test period. The mean carbohydrate intake of about $250 \mathrm{~g}$ was ensured for the old men by communal feeding in the old peoples home. The young men were asked to adhere carefully to a prescribed diet high in carbohydrates. A light occupation in a sitting position was permitted during the trial. Smoking was prohibited. Glucose loading was given in the form of an adequate amount of "Gluco-50" test drink ("Boehringer") dissolved in a specified amount of water $(50 \mathrm{~g}$ glucose in $220 \mathrm{ml}, 75 \mathrm{~g}$ in $330 \mathrm{ml}$ and $100 \mathrm{~g}$ in $440 \mathrm{ml}$ ).

Capillary blood samples were taken from the ear lobe at 8.00 a.m. following a ten-hour fasting period and 60 and $120 \mathrm{~min}$ after the glucose load. Furthermore, blood samples were taken $180 \mathrm{~min}$ after a $100 \mathrm{~g}$ glucose load from 10 of the young men. Blood sugar was determined by Auto-Analyzer (Technicon).

\section{Results}

\section{Fasting blood sugar levels (Table 2)}

The average of mean individual fasting blood sugar levels was lower in the young men $(83.7 \mathrm{mg}$ per $100 \mathrm{ml})$ than the old $(91.4 \mathrm{mg}$ per $100 \mathrm{ml})$. The average of individual variation coefficients ${ }^{1}$, however, was similar for both groups (25.2 for the young and 25.8 for the old).

If one excludes the subject ("no. 20") who developed diabetes, the average of the individual variation coefficients for the old men becomes less than that for the young. The average of mean individual fasting blood sugar levels, however, remains greater than that of the younger group, though the difference is not significant.

1 The variation coefficient indicates the relation between standard deviation and mean blood sugar. 
Table 1. Group of subjects

\begin{tabular}{|c|c|c|c|c|c|c|c|c|c|}
\hline \multirow[t]{2}{*}{$\begin{array}{l}\text { Number } \\
\text { of cases }\end{array}$} & \multirow[t]{2}{*}{$\begin{array}{l}\text { Age } \\
\text { (years) }\end{array}$} & \multirow{2}{*}{\multicolumn{2}{|c|}{$\begin{array}{l}\text { Mean age } \\
\text { (years) }\end{array}$}} & \multirow{2}{*}{$\begin{array}{l}\text { Percentage } \\
\text { deviation } \\
\text { from ideal } \\
\text { weight } \\
\text { (per cent) }\end{array}$} & \multicolumn{2}{|c|}{$\begin{array}{l}\text { Average percentage } \\
\text { deviation from } \\
\text { ideal weight }\end{array}$} & \multicolumn{3}{|c|}{$\begin{array}{l}\text { Number of oral glucose } \\
\text { tolerance tests } \\
\text { Amount glucose given }\end{array}$} \\
\hline & & & & & \multicolumn{2}{|c|}{ (per cent) } & $\overline{50 \mathrm{~g}}$ & $75 \mathrm{~g}$ & $100 \mathrm{~g}$ \\
\hline 1 & 34 ) & \multirow{11}{*}{39.4} & \multirow{20}{*}{52.4} & +27.0 & \multirow{20}{*}{\multicolumn{2}{|c|}{+15.4}} & 5 & 5 & 5 \\
\hline 2 & 35 & & & $\begin{array}{r}17.8 \\
\end{array}$ & & & 5 & 5 & 5 \\
\hline 3 & 36 & & & $\begin{array}{r}13.0 \\
+\end{array}$ & & & 5 & 5 & 5 \\
\hline 4 & 37 & & & +17.0 & & & 5 & 5 & 5 \\
\hline 5 & 37 & & & +19.5 & & & 5 & - & - \\
\hline 6 & 40 & & & -1.0 & & & 5 & 5 & 5 \\
\hline 7 & 40 & & & +10.0 & & & 5 & 5 & 5 \\
\hline 8 & 40 & & & +10.0 & & & 5 & 5 & 5 \\
\hline 9 & 43 & & & +7.0 & & & 5 & 5 & 5 \\
\hline 10 & 45 & & & +30.0 & & & 5 & 5 & 5 \\
\hline 11 & 46 & & & +19.0 & & & 5 & 5 & 5 \\
\hline 12 & 59 & \multirow{9}{*}{68.2} & & +11.0 & & & 5 & 5 & 5 \\
\hline 13 & 64 & & & $\begin{array}{r}1.2 \\
-\quad 2.2\end{array}$ & & & 5 & 5 & 5 \\
\hline 14 & 69 & & & +23.0 & & & 5 & 5 & 5 \\
\hline 15 & 69 & & & -23.0 & & & 5 & 5 & 5 \\
\hline 16 & 69 & & & +31.0 & & & 5 & 5 & 5 \\
\hline 17 & 69 & & & -2.0 & & & 5 & 5 & 5 \\
\hline 18 & 70 & & & +4.0 & & & 5 & 5 & 5 \\
\hline 19 & 71 & & & -10.0 & & & 5 & - & - \\
\hline 20 & 74 & & & -12.0 & & & 5 & - & -_ \\
\hline
\end{tabular}

Table 2. Fasting blood sugar levels

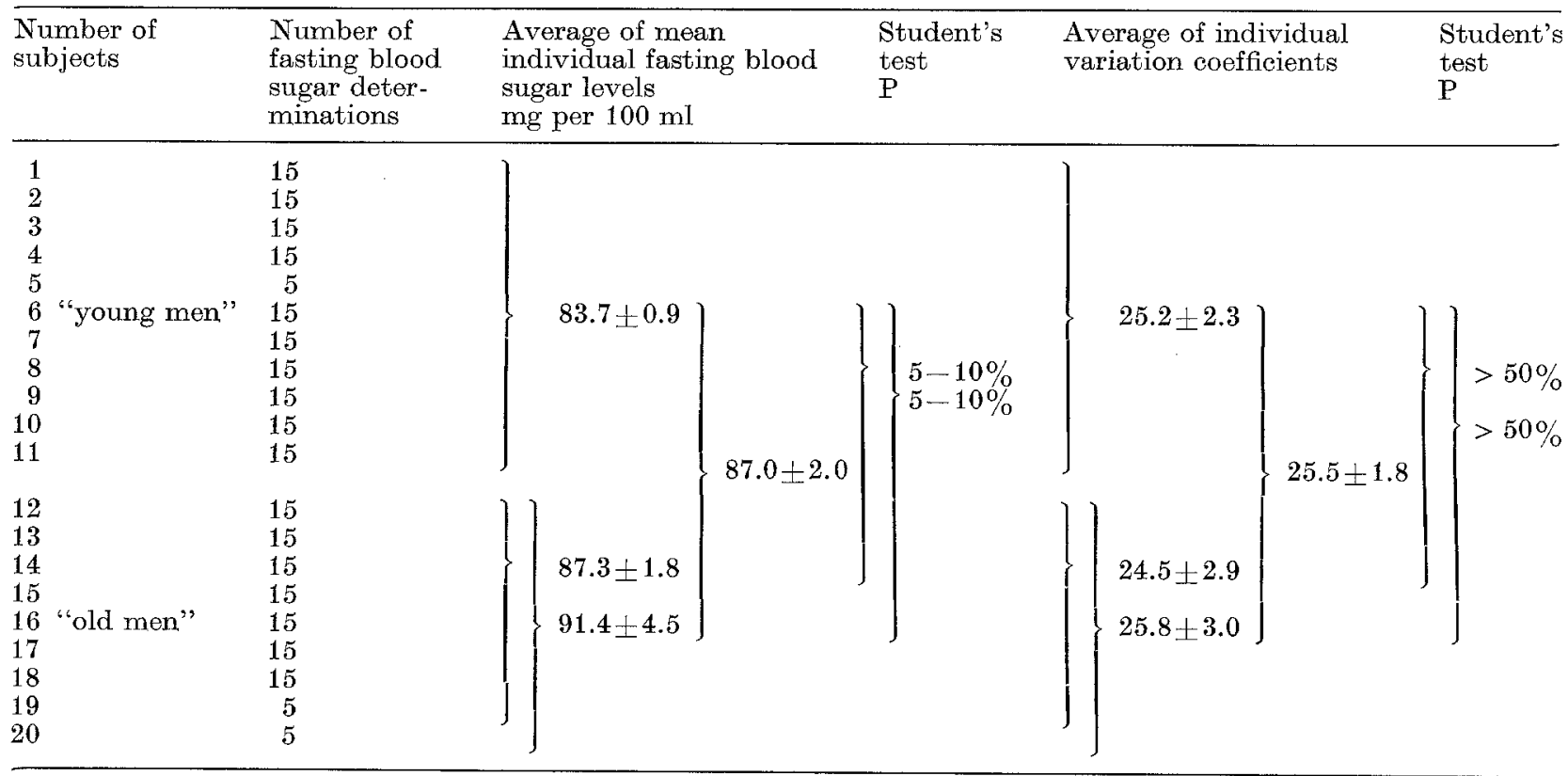

Values \pm behind the mean values are standard errors of mean.

$\mathrm{P}$ means probability.

The variation coefficient indicates the relation between standard deviation and mean blood sugar.

Blood sugar levels 60 min after glucose administration (Table 3)

The average of mean individual blood sugar levels increases with increasing glucose load $60 \mathrm{~min}$ after glucose ingestion. On the contrary, the average of individual variation coefficients decreases with increasing glucose amounts.
The differences between the mean glucose response after the various glucose amounts $(50$ and 75,50 and 100 and 75 and $100 \mathrm{~g}$ ) are not significantly different by Student's test. However, the average of individual variation coefficients after the 50 and $100 \mathrm{~g}$ glucose loads differed with a probability of $1-2$ per cent.

If one separates the young group from the old 
(Table 4 ) the same trend is noted; but a significant difference between average variation coefficients due to the 50 and $100 \mathrm{~g}$ glucose loads is only found in the old men. glucose ingestion. The average of individual variation coefficients, however, decreases from 50 to 100 and from 75 to $100 \mathrm{~g}$ glucose load. There are significant differences between average variation coefficients due

Table 3. Blood sugar levels 60 min after glucose ingestion (all subjects)

\begin{tabular}{|c|c|c|c|c|c|}
\hline $\begin{array}{l}\text { Amount } \\
\text { glucose } \\
\text { given } \\
\text { g }\end{array}$ & $\begin{array}{l}\text { Average of mean individual } \\
\text { blood sugar levels } \\
\text { ( } 5 \text { determinations for } \\
\text { each subject) } \\
\text { mg per } 100 \mathrm{ml}\end{array}$ & $\begin{array}{l}\text { Student's } \\
\text { test } \\
\mathrm{P}\end{array}$ & $\begin{array}{l}\text { Average of individual } \\
\text { variation coefficients }\end{array}$ & $\begin{array}{l}\text { Student's } \\
\text { test } \\
\mathrm{P}\end{array}$ & $\begin{array}{l}\text { Number of } \\
\text { subjects }\end{array}$ \\
\hline 50 & $152.44 \pm 10.89$ & & $30.78 \pm 1.88$ & & 20 \\
\hline 75 & $153.91 \pm 10.64$ & & $28.18 \pm 3.51$ & & 17 \\
\hline 100 & $160.51 \pm 9.30$ & & $22.81 \pm 2.64$ & & 17 \\
\hline
\end{tabular}

Explanations see Table 2.

Table 4. Blood sugar levels 60 min after glucose ingestion for the two age groups

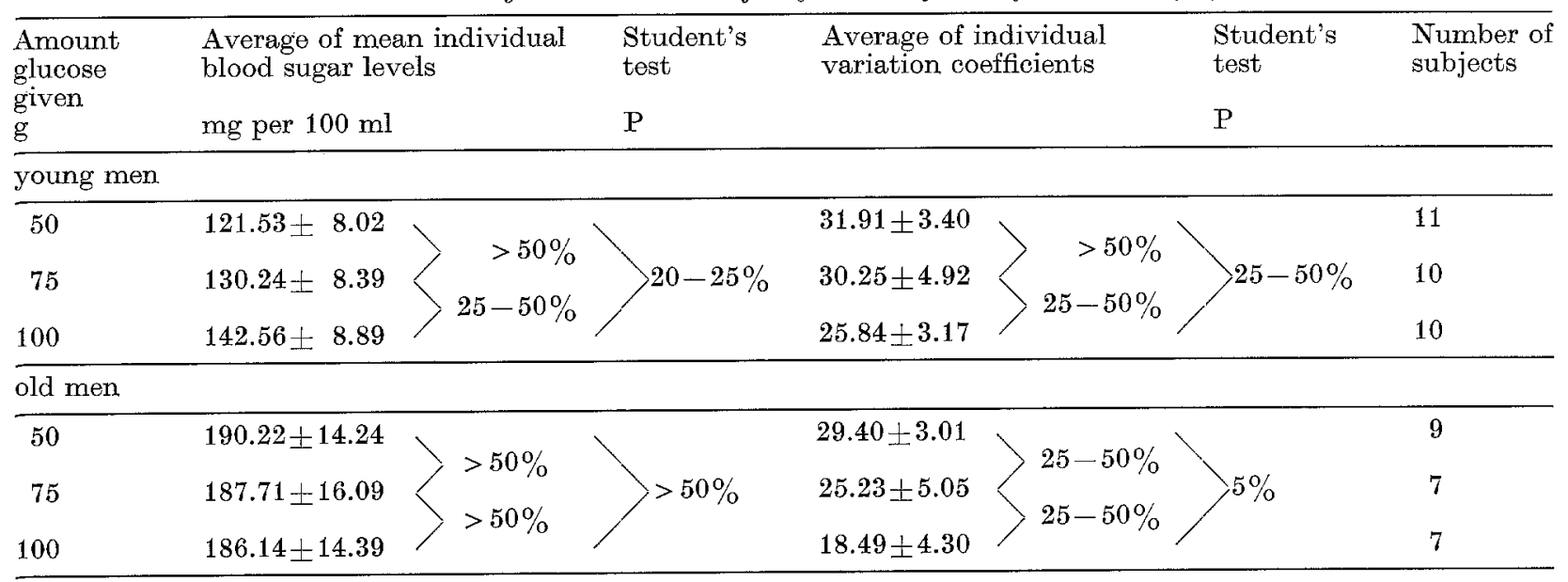

Explanations see Table 2.

Table 5. Blood sugar levels 120 min after glucose ingestion (all subjects)

\begin{tabular}{|c|c|c|c|c|c|}
\hline $\begin{array}{l}\text { Amount } \\
\text { glucose } \\
\text { given } \\
\mathrm{g}\end{array}$ & $\begin{array}{l}\text { Average of mean individual } \\
\text { blood sugar levels } \\
\text { ( } 5 \text { determinations for each } \\
\text { subject) } \\
\text { mg per } 100 \mathrm{ml}\end{array}$ & $\begin{array}{l}\text { Student's } \\
\text { test } \\
\text { P }\end{array}$ & $\begin{array}{l}\text { Average of individual } \\
\text { variation coefficients }\end{array}$ & $\begin{array}{l}\text { Student's } \\
\text { test } \\
\mathrm{P}\end{array}$ & $\begin{array}{l}\text { Number of } \\
\text { subjects }\end{array}$ \\
\hline 50 & $92.96 \pm 7.00$ & & $33.88 \pm 4.09$ & & 20 \\
\hline 75 & $116.02 \pm 8.00$ & 00 & $34.30 \pm 3.82$ & & 17 \\
\hline 100 & $130.20 \pm 5.53$ & & $23.34 \pm 2.97$ & & 17 \\
\hline
\end{tabular}

Explanations see Table 2.

Blood sugar levels 120 min after glucose administration (Table 5)

Glucose given in a dose of $50 \mathrm{~g}$ produces a different response than the 75 and the $100 \mathrm{~g}$ loads. The differences are significantly in the whole group two hours after the glucose load.

The average of mean individual blood sugar levels increases with increasing glucose load 120 min after to amounts of 50 and 100 as well as 75 and $100 \mathrm{~g}$ glucose.

The separate groups of young and old men (Table 6) show the same trend in comparison with the whole group; but there are significant differences between average blood sugar responses after 50 and $100 \mathrm{~g}$ glucose load and between average variation coefficients due to 75 and $100 \mathrm{~g}$ glucose load only in the young group. 
Variances for the various groups of different glucose loads compared by F-test (Table 7)

If one compares the variances ${ }^{2}$ for the groups given different glucose loads, a lower result for the variances to those of the whole group. For young men there are significant differences only between the variances of 50 and 75 and of 50 and $100 \mathrm{~g}$ glucose $120 \mathrm{~min}$ after the glucose load.

Table 6. Blood sugar levels 120 min after glucose ingestion for the two age groups

\begin{tabular}{|c|c|c|c|c|c|}
\hline $\begin{array}{l}\text { Amount } \\
\text { glucose } \\
\text { given } \\
\text { gi }\end{array}$ & $\begin{array}{l}\text { Average of mean individual } \\
\text { blood sugar levels } \\
\text { mg per } 100 \mathrm{ml}\end{array}$ & $\begin{array}{l}\text { Student's } \\
\text { test } \\
\mathrm{P}\end{array}$ & $\begin{array}{l}\text { Average of individual } \\
\text { variation coefficients }\end{array}$ & $\begin{array}{l}\text { Student's } \\
\text { test } \\
\text { P }\end{array}$ & $\begin{array}{l}\text { Number of } \\
\text { subjects }\end{array}$ \\
\hline \multicolumn{6}{|c|}{ young men } \\
\hline 50 & $71.24 \pm 3.56$ & & $29.81 \pm 2.65$ & & 11 \\
\hline 75 & $94.64 \pm 6.06$ & $<0.1 \%$ & $38.08 \pm 4.20<1-$ & & 10 \\
\hline 100 & $116.36 \pm 4.56$ & & $23.04 \pm 3.68$ & & 10 \\
\hline \multicolumn{6}{|l|}{ old men } \\
\hline 50 & $119.51 \pm 8.87$ & & $38.85 \pm 8.48$ & & 9 \\
\hline 75 & $146.57 \pm 8.46$ & $10-20 \%$ & $28.91 \pm 6.98$ & $20-25 \%$ & 7 \\
\hline 100 & $149.97 \pm 6.55$ & & $23.75 \pm 5.28$ & & 7 \\
\hline
\end{tabular}

Explanations see Table 2.

Table 7. Variances for the various groups of different glucose loads compared by $F$-test for all subjects

\begin{tabular}{|c|c|c|c|c|c|c|}
\hline $\begin{array}{l}\mathrm{F} \\
\mathrm{P}\end{array}$ & $\begin{array}{l}F \\
P\end{array}$ & $\begin{array}{l}\text { Variances } \\
60 \text { min after } \\
\text { glucose ingestion }\end{array}$ & $\begin{array}{l}\text { Glucose } \\
\text { load } \\
\text { g }\end{array}$ & $\begin{array}{l}\text { Variances } \\
120 \text { min after } \\
\text { glucose ingestion }\end{array}$ & $\begin{array}{l}\mathrm{F} \\
\mathrm{P}\end{array}$ & $\begin{array}{l}\mathrm{F} \\
\mathrm{P}\end{array}$ \\
\hline$\frac{1.82}{0.5-1 \%}$ & $\begin{array}{l}1.07 \\
>5 \% \\
1.71 \\
1-2.5 \%\end{array}$ & $\begin{array}{l}636 \\
595 \\
349\end{array}$ & $\begin{array}{r}50 \\
75 \\
100\end{array}$ & $\begin{array}{l}464 \\
522 \\
306\end{array}$ & $\begin{array}{l}1.12 \\
>5 \% \\
1.70 \\
1-2 \%\end{array}$ & - \\
\hline
\end{tabular}

The variance of each glucose load represents a composed measure of variance by model of variance within the groups of analysis of variance.

Explanations see Table 2.

is found with the $100 \mathrm{~g}$ glucose load than with 50 and $75 \mathrm{~g}$ glucose.

There is no significant association between the variances of the 50 and $75 \mathrm{~g}$ glucose loads; but there is a significant relation between the variances due to 50 and 100 and to 75 and $100 \mathrm{~g}$ glucose loads 60 and $120 \mathrm{~min}$ after glucose administration. This was found for the whole group.

Comparing the separate groups of young and old men (Table 8), the results for the old men are similar

2 Variances were calculated by the following equation:

$\operatorname{var}_{g}=\left(\sum_{k=1}^{n_{g}} S A Q_{k}\right) / d f_{g}$

$d f_{g}=$ degrees of freedom $=n_{g} \times(\mathrm{t}-\mathrm{l})$

$g=$ load

$k \quad=$ characteristic number

$n_{g}=$ number of subjects with the load " $\mathrm{g}$ "

$S A Q_{k}=$ sum of square deviations of 5 tests with the same load of subject " $k$ "

$t \quad=$ number of tests with the same load $=5$.
Blood sugar levels 180 min after a $100 \mathrm{~g}$ glucose load (Table 9)

Blood sugar determinations 180 min after a $100 \mathrm{~g}$ glucose dose were only carried out in 10 young men. The average of mean individual blood sugar values was $75.0 \mathrm{mg}$ per $100 \mathrm{ml}$. The average of individual variation coefficients was 46.5 , a considerably higher value than that 60 and $120 \mathrm{~min}$ after a $100 \mathrm{~g}$ glucose load.

\section{Correlations between corresponding blood sugar responses of different tests}

Correlations between corresponding blood sugar levels of the various tests with the same glucose load also can be a measure of reproducibility. This method was used to find out if the reproducibility changes with the number of tests.

Correlations between two successive tests do not show a trend of changing with the number of tests. No improvement of the reproducibility was apparent. The 
total correlation matrix, comparing one test with another, does not show a clear trend either for the old or young men, or for the 1,2 and $3 \mathrm{~h}$ values.

\section{Conclusion}

According to our results, there are smaller variation coefficients of the glucose response after a $100 \mathrm{~g}$ glucose
This fact prompts us to recommend performing oral glucose tolerance tests with a $100 \mathrm{~g}$ glucose load. However, the above-mentioned results should further be confirmed on larger groups of subjects in particular women, diabetics and obese patients.

Acknowledgement. We are grateful to the male volunteers who participated in this study and to Professor Dr. K. Irmscher (Second Med. Clin., University of Düsseldorf) and his laboratory staff for their co-operation.

Table 8. Variances for the various groups of different glucose loads compared by $F$-test for the two age groups

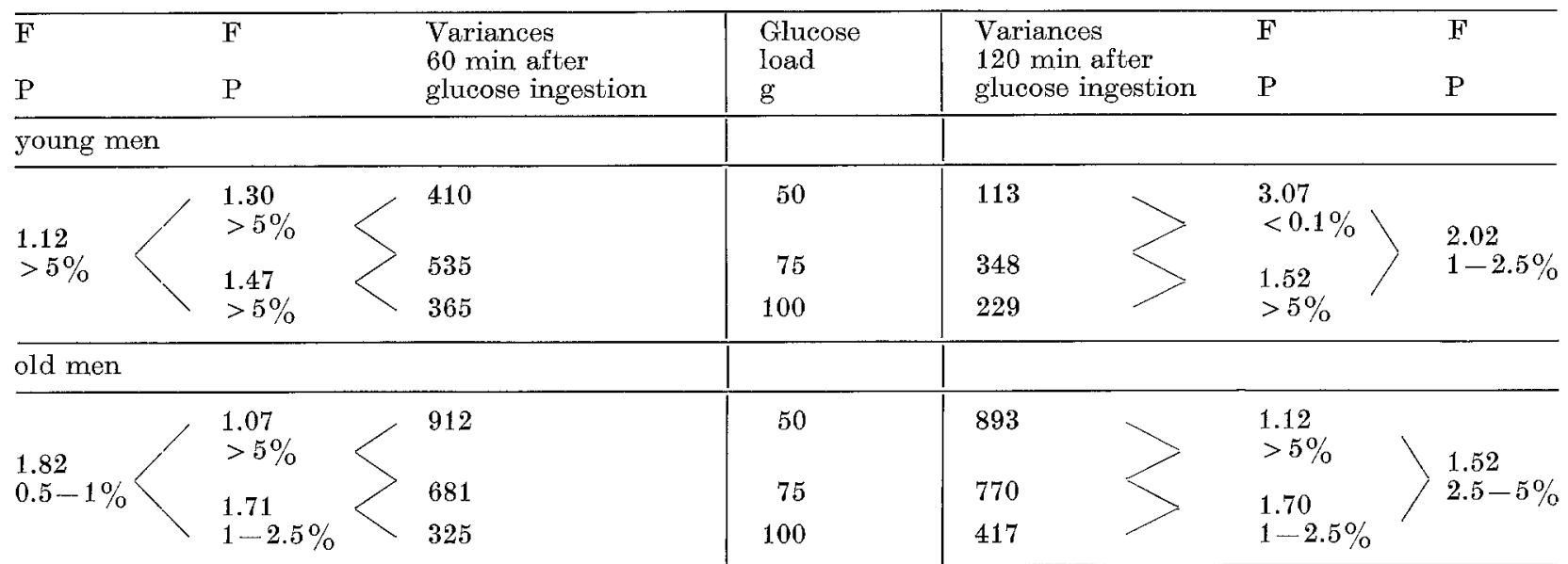

Explanations see Table 7.

Table 9. Blood sugar levels $180 \mathrm{~min}$ after $100 \mathrm{~g}$ glucose load

\begin{tabular}{|c|c|c|c|c|}
\hline $\begin{array}{l}\text { Number } \\
\text { of subjects }\end{array}$ & $\begin{array}{l}\text { Average individual } \\
\text { blood sugar levels } \\
\text { (5 determinations } \\
\text { for each subject) } \\
\text { mg per } 100 \mathrm{ml}\end{array}$ & $\begin{array}{l}\text { Average of mean } \\
\text { individual blood } \\
\text { sugar levels } \\
\text { mg per } 100 \mathrm{ml}\end{array}$ & $\begin{array}{l}\text { Individual variation } \\
\text { coefficients }\end{array}$ & $\begin{array}{l}\text { Average of individual } \\
\text { variation eoefficients }\end{array}$ \\
\hline $\begin{aligned} 1 & \\
2 & \\
3 & \\
4 & \\
5 & \\
6 & \text { "young men" } \\
7 & \\
8 & \\
9 & \\
10 & \\
11 & \end{aligned}$ & $\left.\begin{array}{l}64.8 \pm 8.5 \\
73.2 \pm 12.9 \\
61.2 \pm 8.3 \\
89.2 \pm 31.3 \\
- \pm-\overline{73.2 \pm 10.2} \\
60.0 \pm 9.7 \\
90.0 \pm 22.5 \\
82.0 \pm 16.2 \\
84.8 \pm 21.0 \\
71.6 \pm 20.6\end{array}\right\}$ & $75.0 \pm 3.5$ & $\left.\begin{array}{l}29.5 \\
39.5 \\
30.2 \\
78.5 \\
--\overline{31.3} \\
36.2 \\
55.9 \\
44.0 \\
55.3 \\
64.2\end{array}\right\}$ & $46.5 \pm 5.2$ \\
\hline
\end{tabular}

Explanations see Table 2.

load than after 50 and $75 \mathrm{~g}$. Furthermore, the range of corresponding standard deviations shows generally smaller values for $100 \mathrm{~g}$ than for 50 and $75 \mathrm{~g}$ glucose loads. A comparison of the variances chiefly points to the fact that there is a smaller variation of blood sugar responses after $100 \mathrm{~g}$ glucose intake.

If reproducibility is considered a measure of quality for the tolerance tests, a $75 \mathrm{~g}$ glucose load (e.g. used by Köbberling and Creutzfeldt 1970) does not prove an advantage over a $50 \mathrm{~g}$ glucose load. It seems that only the $100 \mathrm{~g}$ dose effects an impulse of such intensity to make the organism react in a highly specific way.

\section{References}

American Diabetes Association: Standardization of the oral glucose tolerance test. Diabetes 18, 299-307 (1969).

Bock, J.C., Schneider, H., Gilbert, M.: Blood sugar studies. J. biol. Chem. 69, 9-16 (1926).

Castro, A., Scott, J.P., Grettie, D.P., Macfarlane, D., Bailey, R. E.: Plasma insulin and glucose responses of healthy subjects to varying glucose loads during threehour oral glucose tolerance tests. Diabetes 19, $842-851$ (1970).

Freeman, H., Looney, J.M., Hoskins, R.G.: Spontaneous variability of oral glucose tolerance. J. clin. Endoer. 2, $431-434(1942)$. 
Glassberg, B.Y.: The diagnostic value of the sugar tolerance curve in endocrinopathies. Arch. intern. Med. 46, $984-987$ (1930).

Hale-White, R., Payne, W.W.: The dextrose tolerance curve in health. Quart. J. Med, 19, 393-410 (1926).

Hofstatter, L., Sonnenberg, A., Kountz, W.M.B.: The glucose tolerance in elderly patients. Biol. Symposia 11, $87-95(1945)$.

John, H.J.: Glucose tolerance studies in children and in adolescents. Endocrinology 18, 75-85 (1934).

Knußmann, R., Toeller, M., Holler, H.D.: Zur Beurteilung des Körpergewichts. Med. Welt 15, 529-535 (1972).

Köbberling, H., Creutzfeldt, W.: Comparison of different methods for the evaluation of the oral glucose tolerance test. Diabetes 19, 870-877 (1970).

Lennox, W.G.: Blood sugar. Arch. intern. Med. 40, 182$194(1927)$.

McDonald, G.W., Fisher, G.F., Burnham, C.: Reproducibility of the oral glucose tolerance test. Diabetes $\mathbf{1 4}$, $473-480(1965)$.

Maclean, H., de Wesselow, O.L.V.: The estimation of sugar tolerance. Quart. J. Med. 14, 103-119 (1921).

Metropolitan Life Insurance Company: Overweight. Statistical Bulletin 40 (1959).
Mosenthal, H.O.: Interpretation of glucose tolerance tests. Med. Clin. N. Amer. 31, 299-312 (1947).

Mosenthal, H.O., Barry, E.: Criteria for an interpretation of normal glucose tolerance tests. Ann. intern Med. 33, $1175-1194$ (1950).

Spence, J.C.: Some observations on sugar tolerance, with special reference to variations found at different ages. Quart. J. Med. 14, 314-326 (1921).

Stich, W., Wolff, G.: Anwendung und Beurteilung der Traubenzuckerbelastungsproben. Med. Welt 49, 15351540 (1951).

Teuscher, A., Richterich, R.: Neue schweizerische Richtlinien zur Diagnose des Diabetes mellitus. Schweiz. med. Wschr. 101, 345-352 (1971).

Unger, R.H.: The standard two-hour oral glucose tolerance test in the diagnosis of diabetes mellitus in subjects without fasting hyperglycemia. Ann. intern. Med. 47, 1138-1153 (1957).

Dr. Monika Toeller

Professor Dr. R. Knußmann

Diabetes Research Institute at the

University of Düsseldorf

D-4000 Düsseldorf-Benrath

Hospitalstr. 1

Federal Republic of Germany 